\section{Effects of Interspecific Grafting Between Capsicum Species on Scion Fruit Quality Characteristics}

\author{
Andrey Vega-Alfaro \\ Department of Horticulture, University of Wisconsin, Madison, 1575 \\ Linden Drive, Madison, WI 53706
}

Paul C. Bethke

USDA ARS, Vegetable Crops Research Unit, 1575 Linden Drive, Madison, WI 53706; and Department of Horticulture, University of Wisconsin, Madison, 1575 Linden Drive, Madison, WI 53706

\section{James Nienhuis \\ Department of Horticulture, University of Wisconsin, Madison, 1575 Linden Drive, Madison, WI 53706}

Additional index words. Capsicum annuum, C. baccatum, C. chinense, capsaicin, grafting, pepper fruit quality

\begin{abstract}
Production of Capsicum annuum peppers is often limited, especially in tropical environments, by susceptibility to soil pathogens including Ralstonia solanacearum. Grafting desirable cultivars onto selected rootstocks can increase adaptation to abiotic stress and is an alternative to pesticides for managing soilborne pathogens. Cultivars of two other pepper species, Capsicum baccatum and Capsicum chinense, are tolerant or resistant to an array of soilborne pathogens and have potential as rootstocks; however, knowledge of how interspecific grafting may affect scion fruit quality is lacking. Flowering time, yield, and fruit quality characteristics were evaluated in 2017 and 2020 for $C$. annuum cultivars Dulcitico, Nathalie (2017), Gypsy (2020), and California Wonder used as scions grafted onto Aji Rico ( $C$. baccatum) and Primero Red $(C$. chinense) rootstocks, including self-grafted and nongrafted scion checks. In 2020, the rootstocks per se were evaluated. The two rootstocks ('Aji Rico' and 'Primero Red'), three scions, and self- and nongrafted scions were evaluated using a factorial, replicated, completely randomized design in fields at the West Madison and Eagle Heights Agricultural Research Stations located in Madison, WI, in 2017 and 2020, respectively. Differences among the main effects for scion fruit quality characteristics were consistent with cultivar descriptions. No scion $\times$ rootstock interactions were observed. Rootstocks did not result in changes in total fruit number, yield, fruit shape (length-to-width ratio), or soluble solids of scion fruit compared with self- and nongrafted checks. The rootstock 'Primero Red' increased fruit weight and decreased time to flowering regardless of scion compared with self- and nongrafted checks. All scions were sweet (nonpungent) cultivars and both rootstocks were pungent cultivars. No capsaicinoids were detected in the fruit of sweet pepper scions grafted onto pungent pepper rootstocks. The results indicate that interspecific grafts involving 'Aji Rico' and 'Primero Red' will not have deleterious effects on fruit quality characteristics of sweet pepper scions.
\end{abstract}

Grafting is used for an array of vegetables, including tomatoes, cucurbits, and peppers. Grafting can improve agronomic characteristics, abiotic stress resistance, fruit quality, and yield compared with nongrafted plants (Devi et al., 2020; Penella et al., 2017; Sabatino et al., 2018; Suchoff et al., 2019). In some cases, rootstocks provide scions an altered root architecture that reduces requirements for water and fertilizer inputs compared with

Received for publication 26 Apr. 2021. Accepted for publication 2 Aug. 2021.

Published online 27 September 2021.

J.N. is the corresponding author. E-mail: nienhuis@wisc.edu.

This is an open access article distributed under the CC BY-NC-ND license (https://creativecommons. org/licenses/by-nc-nd/4.0/).
2008; Haroldsen et al., 2012; Warschefsky et al., 2016). In some cases, desirable changes in scion fruit occur after grafting, and an emerging use of grafting in solanaceous and cucurbit crops is to improve fruit quality traits, including color, shape, size, and organoleptic characteristics (Attavar et al., 2020; Devi et al., 2021; Kyriacou et al., 2017).

Rootstock effects on fruit quality characteristics are often inconsistent across scions. The reconnection of vascular continuity between different rootstock and scion genotypes, compounded by the intermediate formation of callus, may alter the flow rate of metabolites across the graft union, resulting in changes in scion morphology and fruit characteristics (Berger et al., 2018; Davis et al., 2008). Moreover, grafting may trigger epigenetic changes that alter the transcription of genes in the scion (Li et al., 2021; Karaca et al., 2020). In peppers, desirable and often undesirable changes in fruit shape, size, and weight have been observed after grafting (Doñas-Uclés et al., 2015; Kyriacou et al., 2017). In addition, changes in antioxidant levels and nutritional content have been observed in specific pepper rootstock-scion combinations (Padilla et al., 2021; Sánchez-Chávez et al., 2015). Previous studies have reported dramatic changes in fruit shape, plant habit, and capsaicin content in scions of pungent pepper 'Yatsubusa' grafted onto nonpungent 'Spanish Paprika' rootstocks, both C. annuum (Taller et al., 1998, 1999; Yagishita and Hirata, 1986, 1987; Yagishita et al., 1985, 1990). The pungent alkaloids capsaicin and dihydrocapsaicin are synthesized directly from two precursors, vanillylamine and a 9-11 carbon fatty acid (Johnson et al., 1996; Kim et al., 2009, 2014). Capsaicinoid content in mature fruit is an important quality parameter of both pungent and nonpungent peppers. Graftinduced changes in scion fruit shape, plant habit, and capsaicin content observed in grafted 'Yatsubusa' were hypothesized to be due to chromatin movement through the graft junction (Ohta, 1991). These changes, however, are more likely attributable to stable, epigenetic events, given that graft-induced changes were transmitted to progeny through multiple generations of selfing (Tsaballa et al., 2021; Wu et al., 2013).

C. annuum production is challenging due to abiotic and biotic stresses that can limit marketable yield, and grafting is being actively investigated as a technology that might allow pepper production to expand into regions where disease pressure and abiotic stress limit production (Fisk, 2017; Mamphogoro et al., 2020). In tropical environments, field-based pepper production is often precluded due to soil pathogens such as Ralstonia solanacearum and Phytophthora capsici (Barchenger et al., 2018; Rivard et al., 2012). Interspecific grafting of $C$. annuum cultivars onto diseaseresistant $C$. chinense and $C$. baccatum rootstocks is being investigated as a technology for management of soil pathogens in tropical environments (Vega-Alfaro, 2020). Previous research using interspecific grafting of $C$. annuum cultivars onto $C$. chinense and 
C. baccatum focused on salt and water stress management (Penella et al., 2017, 2015). The objective of this research was to investigate changes in fruit quality characteristics, including capsaicinoid content, in interspecific grafts using $C$. annuum cultivars as scions and C. chinense and C. baccatum cultivars as rootstocks.

\section{Materials and Methods}

Plant material. The $C$. annuum cultivars used as scions are sweet (nonpungent) peppers. 'Dulcitico' and 'California Wonder 300 TMR' ('California Wonder' throughout the article) were used in both 2017 and 2020 (Table 1). 'Nathalie' was used in 2017 only, because of a shortage of 'Nathalie' seed in 2020. 'Gypsy', a sweet pepper with characteristics similar to 'Nathalie' and in the same market class, lamuyo, was substituted for 'Nathalie' in 2020. Seed of 'Dulcitico' was purchased from Fabio Baudrit Moreno Agricultural Research Station, Universidad de Costa Rica (Alajuela, Costa Rica), and 'Nathalie' seed was purchased from Vivero Rincón de Paz (Sarchí, Costa Rica). 'Gypsy' was purchased from Osborne Quality Seeds (Mount Vernon, WA). Cultivars used as rootstocks were Aji Rico (C. baccatum) and Primero Red (C. chinense). Both cultivars produce pungent fruit and were developed for adaptation to temperate climates, early maturity, improved fruit size, and red fruit color (Table 1). Both are licensed by PanAmerican Seed (West Chicago, IL).

Grafting procedure. Plants were grafted on 17 May 2017 and 25 May 2020 using the splice method as described by Lee et al. (2010). Immediately after grafting, plants were placed in a healing chamber for $7 \mathrm{~d}$. Average daily relative humidity, temperature, and photosynthetic photon flux density inside the chamber during the 7-day healing period were $92 \%, 23{ }^{\circ} \mathrm{C}$, and $130 \mu \mathrm{mol}$ photons $/ \mathrm{m}^{2} / \mathrm{s}$, respectively, in 2017 and $98 \%, 26^{\circ} \mathrm{C}$, and $130 \mu \mathrm{mol}$ photons $/ \mathrm{m}^{2} / \mathrm{s}$ in 2020 . Eight days after grafting, plants were acclimatized for an additional 8 to $10 \mathrm{~d}$ at the University of Wisconsin-Madison Walnut Street (2017) and King Hall (2020) greenhouses. Average daily relative humidity and temperature during the acclimation period were $67 \%$ and $22^{\circ} \mathrm{C}$ in 2017 and $62 \%$ and $23^{\circ} \mathrm{C}$ in 2020 .

Plant establishment and maintenance. Grafting combinations, as well as self- and nongrafted checks of each scion genotype were transplanted 15 to $17 \mathrm{~d}$ after grafting to research plots at the West Madison (on 2 June 2017) and Eagle Heights (on 10 June 2020) Agricultural Research Stations. Soil type is Mollic Hapludalfs at West Madison and Typic Hapludalfs at Eagle Heights. Rows were covered with soil-biodegradable white plastic mulch (Organix A.G Film; Organix Solutions, Bloomington, MN) before planting. Rows were spaced $1.20 \mathrm{~m}$ apart and plant spacing was $0.45 \mathrm{~m}$. Individual plants were hand fertilized with water-soluble Peter's Brand 20N-4.4P-16.6K (ICL SF, Dublin, $\mathrm{OH})$ at a rate of $112 \mathrm{~kg} \cdot \mathrm{ha}^{-1} \mathrm{~N}$ distributed in four biweekly applications starting the week of transplanting. Weeds were controlled manually. Insect pests were controlled as needed based on weekly scouting, and thresholds were reported by the local extension agency (Knuteson et al., 2010).

Experiment design and measurements. The experiment was a factorial of two rootstocks and three scions evaluated as a completely randomized design with four (2017) and six (2020) replications. The experimental unit consisted of a single plant. Self- and nongrafted scions were included as checks. Additional nongrafted rootstock genotypes, referred as "rootstocks per se", were included in 2020 as capsaicinoid controls. Approximately $3 \%$ of grafted plants were discarded before transplanting because of undesirable adventitious roots growing near the graft junction (VegaAlfaro et al., 2021). After transplanting, any additional vegetative growth forming near the graft junction was removed at very early stages of development. Flowering time and fruit traits on the rootstocks per se were harvested and evaluated using the same methods as those used for the other graft treatments. Time to flowering was the number of days after transplanting until at least one fully opened flower was observed. All fruit were allowed to open pollinate naturally, and fruit at commercial maturity were harvested 84 and $105 \mathrm{~d}$ after transplanting. Yield for each plant was the combined yield from both harvests. Fruit weight was calculated by dividing total yield by the number of fruit per replication. Four representative fully mature fruit per plant for all rootstock-scion combinations and checks were used in assays for fruit quality variables including length-to-width ratio, soluble solids, capsaicinoid content, and $\mathrm{pH}$. For fruit quality variables, four fruit from the first harvest were processed unless there were fewer than four fruit, in which case the remaining number of fruit came from the second harvest. Length-towidth ratio was measured by dividing maximum fruit length by the width at $50 \%$ of length using a caliper (Fisherbrand Traceable; Fischer Scientific, Waltham, WA). For soluble solids and $\mathrm{pH}$ measurements, individual fruit samples were blended, and the pulp was removed by filtering the homogenate with filter paper (Whatman no. 1; Whatman, Maidstone, UK). Total soluble solids were determined with a portable refractometer (RF15; Extech Instruments, Nashua, $\mathrm{NH}$ ) and $\mathrm{pH}$ was measured using a portable $\mathrm{pH}$ meter (accumet AP125; Fischer Scientific, Waltham, WA). Values for length-to-width ratio, $\mathrm{pH}$, and soluble solids used for statistical analysis were the means of individual measurements of four fully developed fruit from each experimental unit.

High-performance liquid chromatography separation of capsaicinoids. Sample preparation was performed following the method described by Collins et al. (1995) with modifications. Briefly, four pepper fruit placentas from each replicate were pooled, coarsely chopped, frozen at $-80^{\circ} \mathrm{C}$ for $72 \mathrm{~h}$, lyophilized, and pulverized by shaking with 4.5$\mathrm{mm}$ metal beads using a modified electric paint shaker. Pulverized placenta samples were mixed with acetonitrile at a ratio of $1 \mathrm{~g}$ sample to $10 \mathrm{~mL}$ acetonitrile in centrifuge tubes, extracted in a water bath for $4 \mathrm{~h}$ at $65^{\circ} \mathrm{C}$ and centrifuged at $1800 \mathrm{~g}_{\mathrm{n}}$ at $20^{\circ} \mathrm{C}$ for $10 \mathrm{~min}$. Supernatants were filtered using $0.20-\mu \mathrm{m}$ membrane filters (Syringe filter; Corning Inc., Corning, NY), placed in autosampler vials, and stored at $-20^{\circ} \mathrm{C}$ until used for capsaicinoid analysis.

Capsaicin and dihydrocapsaicin were quantified using high-performance liquid chromatography (HPLC) with a Shimadzu

Table 1. Origin, plant and fruit characteristic of cultivars of Capsicum annuum, Capsicum baccatum, and Capsicum chinense used as scions or rootstocks in interspecific graft combinations.

\begin{tabular}{|c|c|c|c|c|c|c|c|}
\hline \multirow[b]{2}{*}{ Variety name } & \multirow[b]{2}{*}{ Species } & \multirow[b]{2}{*}{ Breeder $(y r)^{z}$} & \multirow{2}{*}{$\begin{array}{l}\text { Maturity } \\
(\mathrm{d})^{\mathrm{z}}\end{array}$} & \multicolumn{4}{|c|}{ Fruit } \\
\hline & & & & $\operatorname{Size}^{\mathrm{x}}(\mathrm{mm})$ & Color & Type & Pungency \\
\hline \multicolumn{8}{|l|}{ Scions } \\
\hline $\begin{array}{l}\text { California Wonder } \\
300 \text { TMR }\end{array}$ & C. anпиит & Carolina Seeds (1999) & 72 & $110 \times 100$ & Green to red & Blocky Bell & No \\
\hline Dulcitico $F_{1}$ & C. аппиит & $\begin{array}{r}\text { Echandi, C; Univ. of } \\
\text { Costa Rica (2013) }\end{array}$ & 95 & $130 \times 60$ & Green to red & Lamuyo & No \\
\hline Nathalie (PEP 2129) & C. anпиит & Petoseed (1980) & 105 & $140 \times 65$ & Green to red & Lamuyo & No \\
\hline Aji Rico $F_{1}^{y}$ & C. baccatum & PanAmerican Seed (2017) & 70 & $95 \times 35$ & Green to red & Aji & Mildly hot \\
\hline Primero Red $\mathrm{F}_{1}^{\mathrm{y}}$ & C. chinense & PanAmerican Seed (2016) & 75 & $80 \times 35$ & Green to red & Habanero & Hot \\
\hline
\end{tabular}




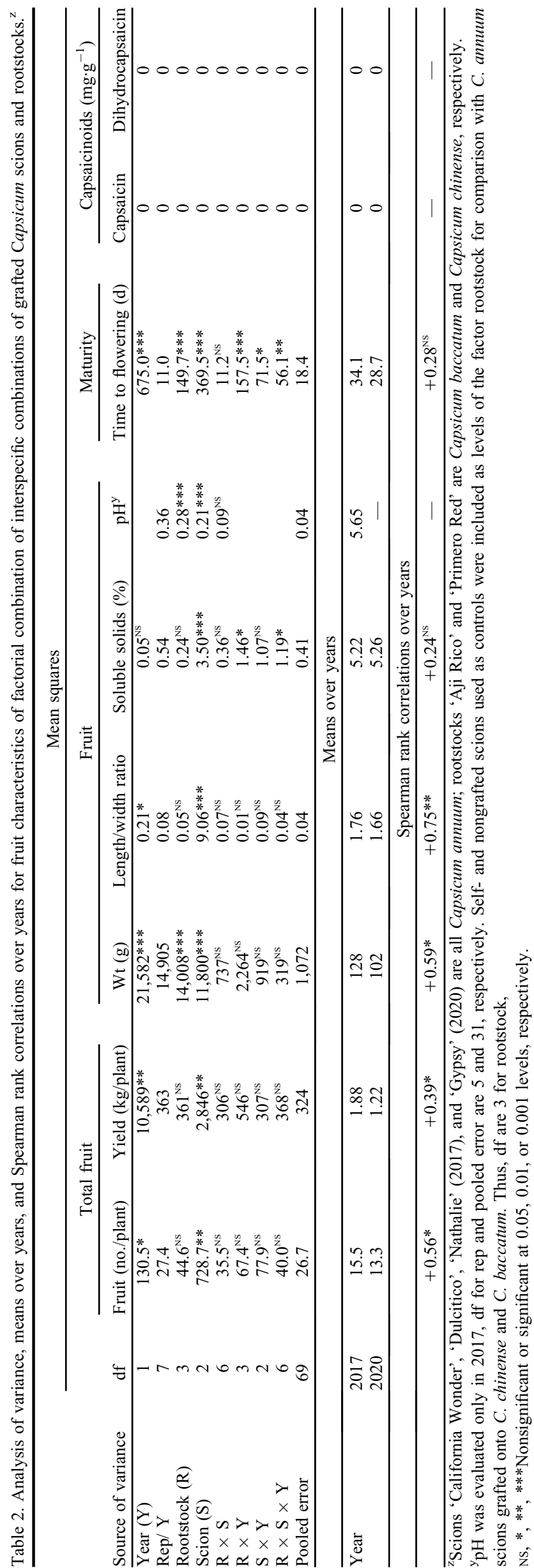

Prominence HPLC system (Shimadzu Scientific Instruments, Columbia, MD) equipped with a SPD-M20A diode array detector. Samples $(2 \mu \mathrm{L})$ were separated with a $100 \times 2.1$ $\mathrm{mm} 3-\mu \mathrm{m}$ Shimadzu Premier C18 column having a 120 angstrom pore size at $50{ }^{\circ} \mathrm{C}$ and a flow rate of $0.5 \mathrm{~mL} \cdot \mathrm{min}^{-1}$. Mobile phase $\mathrm{A}$ consisted of $40 \% \mathrm{v} / \mathrm{v}$ acetonitrile and $0.1 \%$ $\mathrm{v} / \mathrm{v}$ phosphoric acid and mobile phase $\mathrm{B}$ was $90 \% \mathrm{v} / \mathrm{v}$ acetonitrile and $0.1 \% \mathrm{v} / \mathrm{v}$ phosphoric acid. Mobile phase B increased linearly from $0 \%$ to $7 \%$ over the first $3 \mathrm{~min}$ of the run and from $7 \%$ to $70 \%$ from 3 to $16 \mathrm{~min}$. Total run time was $25 \mathrm{~min}$, with $0 \% \mathrm{~B}$ from 16 to 25 min. Capsaicin and dihydrocapsaicin were identified using the signal at $200 \mathrm{~nm} \pm 2 \mathrm{~nm}$ based on characteristic retention times and quantified based on peak area and a calibration curve produced from capsaicin and dihydrocapsaicin standards. The limit of detection for capsaicin and dihydrocapsaicin was less than $0.1 \mathrm{ppm}$ and $0.5 \mathrm{ppm}$, respectively.

Statistical analysis. Yield and time to flowering were Box-Cox transformed to better approximate normality and fulfill the assumptions for analysis of variance (ANOVA) and mean separation procedures; however, for clarity, means in tables for all variables are presented untransformed.

Year, rootstock, scion, and their interactions were fit as a full factorial, repetition was nested within year. Rootstocks per se were included as capsaicinoid controls in the analysis. The ANOVA, least square means, correlations, and mean separation procedures for all the variables were estimated using the statistical software JMP Pro (Version 15; SAS Institute, Cary, NC). Pairwise comparisons were made using the LSmeans statement and Tukey's honestly significant difference at an alpha level of 0.05 .

\section{Results and Discussion}

Average air temperature $\left(19.8\right.$ and $\left.20.4{ }^{\circ} \mathrm{C}\right)$ and cumulative rainfall (442 and $480 \mathrm{~mm}$ ) during the growing season (June-September) in 2017 and 2020, respectively, were generally favorable for field-grown peppers. Field trials in the intermediate years of 2018 and 2019 were lost due to excessive rainfall and flooding. Variation in temperature and rainfall patterns in 2017 and 2020 may have contributed to significant differences between years for all variables except fruit soluble solids and capsaicinoid content (Table 2). Significant rootstock by year and scion by year interactions were observed for time to flowering (Table 2). The lack of significance for other scion by year interactions indicates that the ranking of scion fruit characteristics was similar over years despite substituting scion cultivar Gypsy for Nathalie in 2020 (Table 2). Spearman rank correlations of the rootstock by scion interactions over years were positive and significant for all variables except soluble solids and time to flowering, the only two variables in which significant second-order interactions involving rootstocks by scion by year were also observed (Table 2). The sign and rank of the correlations and lack of interactions with years indicates 
that performance of the factorial set of rootstock-scion combinations were repeatable over years for all variables except soluble solids and time to flowering.

In grafting experiments, selecting the appropriate check (i.e., self- vs. nongrafted) is an experimental design choice that depends on the hypothesis being tested. Self-grafted checks are the appropriate checks for experimental designs in which both scion and rootstock have experienced a shared physiological stress, including stem wounding, callus proliferation in the graft union, and differentiation of new vascular tissues within the graft union; thus, the differential in the response between grafted and self-grafted plants could be plausibly attributed to differences between rootstocks. In contrast, a vegetable grower might be interested in comparing a nongrafted cultivar with a cultivar used as a scion grafted onto a rootstock. The appropriate check in this case is the nongrafted plant, as the grower's interest is a comparison of added value vs. cost of grafting. In this experiment, differences between self- and nongrafted checks were observed only for fruit $\mathrm{pH}$ and time to flowering (Table 3). Nongrafted plants have not been exposed to developmental stresses associated with grafting and recovery; thus, comparisons with grafted plants are confounded. Nevertheless, in a recent meta-analysis of 54 papers comparing self- and nongrafted tomato (Solanum lycopersicum L.), an overall ratio of 0.99 was observed between the yield of self- and nongrafted plants (Grieneisen et al., 2018). In tomato grafting studies conducted in tropical Guatemala and Honduras, self-grafted plants had higher yield compared with nongrafted cultivars in soils containing known levels of inoculum of root pathogens, including Ralstonia solanacearum (Gutiérrez-Benites, 2018). This suggests that grafting alone may shield the otherwise susceptible scions by priming the grafting-induced systemic resistance at early stages of development or by affecting the movement of the xylem-dwelling pathogens to the grafted scion (Berger et al., 2018; Guan et al., 2012).

Differences among scions, regardless of rootstock, were consistent with cultivar descriptions (Tables 2 and 3). Moreover, no rootstock by scion interactions were observed for fruit number, yield, or quality characteristics, including capsaicinoid content. Differences among rootstocks were observed; nevertheless, the rootstocks had similar effects on all scions for all measured variables (Tables 2 and 4). Thus, no exceptional rootstock-scion combinations were observed for fruit characteristics.

Differences among main effects of rootstocks were observed for fruit weight, $\mathrm{pH}$, and time to flowering (Table 2). Fruit of the two rootstocks per se were $\approx 10$ times more numerous and weighed one-tenth as much compared with fruit from grafted and nongrafted scions. Despite this, an increase in fruit weight was observed on scions grafted onto 'Primero Red' compared with self- and nongrafted checks (Table 3). These results highlight the finding that fruit from scions did not acquire individual fruit weight characteristics inherent to the rootstock; instead, an increase in fruit weight was observed, likely due to the enhanced root architecture of the rootstock. Increases in fruit weight of grafted $C$. annuum cultivars also have been observed in field-grown plants in Almería, Spain; but only for the specific combinations of Jalapeño and SCM-334 rootstocks and the scion Palermo (Doñas-Uclés et al., 2015). In high-tunnel evaluations, increases in total fruit weight, number of fruit per plant, and fruit weight per square meter were observed in specific rootstock-scion combinations among a factorial set of four commercial cultivars grafted onto five rootstocks with resistance to soilborne pathogens, all C. annuum (Soltan et al., 2017). Reduction in fruit size has been reported in intraspecific
C. annuum 'Yatsubusa' scions grafted onto 'Spanish Paprika' (Yagishita, et al., 1985). In the current study, no increases in fruit number or yield were observed in scions grafted onto either rootstock compared with self- and nongrafted checks, and no rootstock-scion interactions were observed (Tables 2-4). In a parallel experiment, yield increases were observed when $C$. annuum scions were grafted onto 'Primero Red' in field plantings in tropical San Carlos, Costa Rica (Vega-Alfaro, 2020). The observed increase in yield could be partially attributed to the resistance of $C$. chinense cultivars to soilborne pathogens, including Ralstonia solanacearum (Jang et al., 2012). Scions grafted onto 'Aji Rico' had reduced time to flowering compared with self- and nongrafted checks (Table 3). The rootstock 'Aji Rico' is a C. baccatum cultivar bred specifically for early maturity (J. Nienhuis, unpublished data). Significant rootstock by scion interactions were not observed for time to flowering (Tables 2 and 4). Thus, the effect of rootstock 'Aji Rico' on reduced flowering time was consistent regardless of the scion or production environment. In a parallel study, reduced time to flowering was also observed in scions grafted onto 'Aji Rico' in field plantings in tropical San Carlos, Costa Rica (Vega-Alfaro, 2020). Rootstocks may significantly impact scion maturity by altering the production and passage of flowering stimuli, plant hormones, enzymes, soluble RNAs and messenger RNAs, or by modifying the gene expression of floweringrelated loci in the scion (Pant et al., 2008; Wada and Takeno, 2010). Studies in another solanaceous crop, potato (Solanum tuberosum), have shown that signals for flowering and tuber induction are graft-transmissible (Martin et al., 2009; Navarro et al., 2011). Taken together, the maturity data indicate that grafting does not delay the transition to maturity of grafted plants as compared with nongrafted plants, even though grafted pepper

Table 3. Factorial means and mean separation for main effects of scions, rootstocks, and rootstocks per se associated with interspecific Capsicum graft combinations. $^{\mathrm{z}}$ Self-grafted includes data for Capsicum annuиm scions grafted onto rootstocks of the scion genotype. Nongrafted includes data for the three Capsicum annuum genotypes used for scions.

\begin{tabular}{|c|c|c|c|c|c|c|c|c|c|}
\hline & \multicolumn{2}{|c|}{ Total fruit } & \multicolumn{4}{|c|}{ Fruit } & \multirow{2}{*}{$\begin{array}{c}\text { Maturity } \\
\text { Time to } \\
\text { flowering (d) }\end{array}$} & \multicolumn{2}{|c|}{ Capsaicinoids $\left(\mathrm{mg} \cdot \mathrm{g}^{-1}\right)$} \\
\hline & $\begin{array}{c}\text { Fruit } \\
\text { (no./plant) }\end{array}$ & $\begin{array}{c}\text { Yield } \\
\text { (kg/plant) }\end{array}$ & Wt $(\mathrm{g})$ & $\begin{array}{l}\text { Length/width } \\
\text { ratio }\end{array}$ & $\begin{array}{c}\text { Soluble } \\
\text { solids (\%) }\end{array}$ & $\mathrm{pH}^{\mathrm{x}}$ & & Capsaicin & Dihydrocapsaicin \\
\hline California Wonder & $8.9 \mathrm{~B}^{\mathrm{y}}$ & $1.21 \mathrm{~B}$ & $138 \mathrm{~A}$ & $1.10 \mathrm{~B}$ & $5.03 \mathrm{~B}$ & $5.67 \mathrm{~A}$ & $34.9 \mathrm{~A}$ & 0 & 0 \\
\hline Dulcitico & $17.0 \mathrm{~A}$ & $1.75 \mathrm{~A}$ & $107 \mathrm{~B}$ & $2.05 \mathrm{~A}$ & $5.07 \mathrm{~B}$ & $5.73 \mathrm{~A}$ & $31.5 \mathrm{~B}$ & 0 & 0 \\
\hline Nathalie/Gypsy & $17.4 \mathrm{~A}$ & $1.70 \mathrm{~A}$ & $99 \mathrm{~B}$ & $1.99 \mathrm{~A}$ & $5.63 \mathrm{~A}$ & $5.50 \mathrm{~B}$ & $27.3 \mathrm{C}$ & 0 & 0 \\
\hline Primero Red & $13.7 \mathrm{~A}$ & $1.68 \mathrm{~A}$ & $137 \mathrm{~A}$ & $1.70 \mathrm{~A}$ & $5.22 \mathrm{~A}$ & $5.45 \mathrm{C}$ & $31.2 \mathrm{~B}$ & 0 & 0 \\
\hline Self-grafted & $15.2 \mathrm{~A}$ & $1.60 \mathrm{~A}$ & $109 \mathrm{~B}$ & $1.70 \mathrm{~A}$ & $5.21 \mathrm{~A}$ & $5.83 \mathrm{~A}$ & $34.7 \mathrm{~A}$ & 0 & 0 \\
\hline Nongrafted & $15.9 \mathrm{~A}$ & $1.52 \mathrm{~A}$ & $102 \mathrm{~B}$ & $1.78 \mathrm{~A}$ & $5.15 \mathrm{~A}$ & $5.65 \mathrm{~B}$ & $30.9 \mathrm{BC}$ & 0 & 0 \\
\hline \multicolumn{10}{|c|}{ Rootstocks per se $e^{x}$} \\
\hline Aji Rico & $152 \mathrm{~A}$ & $1.80 \mathrm{~A}$ & $11.9 \mathrm{~A}$ & $2.75 \mathrm{~A}$ & $8.0 \mathrm{~A}$ & - & $18.4 \mathrm{~A}$ & $4.23 \mathrm{~A}$ & $1.03 \mathrm{~A}$ \\
\hline Primero Red & $183 \mathrm{~A}$ & $2.02 \mathrm{~A}$ & $11.1 \mathrm{~A}$ & $1.80 \mathrm{~B}$ & $5.7 \mathrm{~B}$ & - & $21.8 \mathrm{~A}$ & $12.2 \mathrm{~B}$ & $4.45 \mathrm{~B}$ \\
\hline
\end{tabular}


Table 4. Rootstock $\times$ scion interactions means for fruit characteristics for a factorial set of interspecific Capsicum graft combinations and self- and nongrafted scion checks.

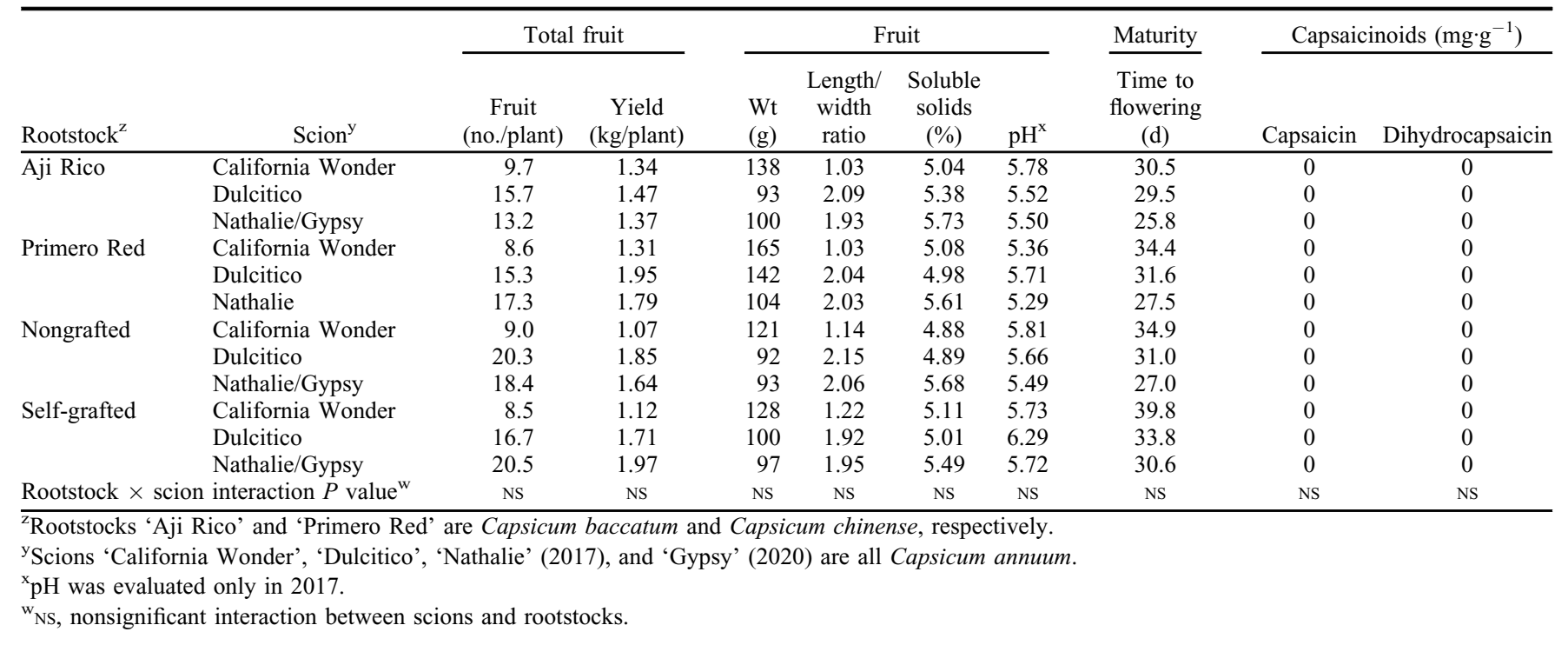

plants go through a 2-week period of healing and acclimation (Table 4).

Scion fruit soluble solids were not changed in grafting combinations compared with self- and nongrafted checks (Table 3). This observation is consistent with reports indicating that intraspecific grafting of peppers did not change scion fruit $\mathrm{pH}$ or soluble solids (Birkás et al., 2021).

Likewise, scion fruit length-to-width ratio (shape) was the same in grafting combinations as in self- and nongrafted checks (Table 3). This result contrasts with the dramatic graftinduced and heritable changes in fruit shape observed when blocky-shaped $C$. annuum 'Yatsubusa' scions were grafted onto conical C. annuum 'Spanish Paprika' and when globeshaped C. annuum 'Mytlini Round' scions wee grafted onto long-shaped $C$. annuum 'Piperaki Long' (Taller et al., 1998; Tsaballa et al., 2013; Yagishita and Hirata, 1987). In the present interspecific grafting study, the only change in fruit quality observed was a reduction in fruit $\mathrm{pH}$ for scions grafted onto rootstock 'Primero Red' (Table 3), highlighting that graft-induced changes in fruit shape might be species or cultivar specific.

'Primero Red' had higher levels of capsaicin and dihydrocapsaicin than 'Aji Rico' (Table 3). The $C$. annuum scions used in this study were all nonpungent sweet peppers (Table 1) and regardless of rootstock, no capsaicinoids were detected in scion fruit (Table 3), and there were no rootstock by scion interactions for fruit capsaicinoid content. Most nonpungent peppers have a four-base mutation in Pun1, the gene responsible for the synthesis of capsaicinoids in the interlocular septa (placenta) of developing fruit (Stewart et al., 2005, 2007). The lack of capsaicin and dehydrocapsaicin in scion fruit, regardless of rootstock, is consistent with the hypothesis that the sweet pepper scions contain a mutation in Punl or other gene responsible for capsaicinoid synthesis or accumulation, and that a graft-transmissible metabolite did not compensate for the mutation. In contrast, capsaicin levels were reduced in pungent 'Yatsubusa' scions grafted onto nonpungent 'Spanish Paprika' (Yagishita and Hirata, 1986, 1987; Yagishita et al., 1990). The reciprocal graft of nonpungent scions grafted onto pungent rootstocks, as is reported in the present study, was not reported by Yagishita and Hirata $(1986,1987)$ or, to our knowledge, in other published literature.

Commercial application of grafting, and even more so interspecific grafting, is not as common in peppers as in other crops, including tomato and watermelon. It may be that the technical challenges associated with grafting are clear, but the benefits are less apparent. Most pepper rootstocks have been developed for resistance to disease and abiotic stress (Leal-Fernández et al., 2013). The results of the current study indicate that interspecific grafting of $C$. annuum scions on $C$. chinense and $C$. baccatum cultivars can result in increased fruit weight and earliness, with no deleterious effects on scion fruit characteristics, including effects on capsaicinoids level. Although no exceptional rootstock $\times$ scion interactions were observed in the present factorial study, further research may identify combinations with unique plant or fruit characteristics. The challenge in identification of exceptional scion-rootstock combinations is that as the number of genotypes increases, the cost of testing factorial combinations becomes exponentially greater in terms of time and resources compared with testing cultivars.

Taken together, the data from the current study suggest that interspecific grafting of nonpungent $C$. annuum cultivars onto pungent $C$. baccatum and $C$. chinense cultivars does not compromise fruit quality characteristics of the scion. On the contrary, individual fruit weight increased with 'Primero Red' rootstocks, likely because of the enhanced root system provided by the rootstock. As expected, capsaicin and dihydrocapsaicin were not detected in fruit harvested from nonpungent scions grafted onto pungent rootstocks. To support the adoption of grafting technology in peppers, additional research efforts and economic analysis are required to clarify the potential benefits of using C. baccatum and $C$. chinense cultivars as rootstocks to manage biotic and abiotic stress.

\section{Literature Cited}

Attavar, A., L. Tymon, P. Perkins-Veazie, and C.A. Miles. 2020. Cucurbitaceae germplasm resistance to verticillium wilt and grafting compatibility with watermelon. HortScience 55:141-148, https://doi.org/10.21273/HORTSCI14631-19.

Barchenger, D.W., K.H. Lamour, and P.W. Bosland. 2018. Challenges and strategies for breeding resistance in Capsicum annuum to the multifarious pathogen, Phytophthora capsici. Front. Plant. Sci. 9:628, https://doi.org/10.3389/ fpls.2018.00628.

Berger, M.M., P. Gallusci, and E. Teyssier. 2018. Roles of epigenetic mechanisms in grafting and possible applications. Adv. Bot. Res. 88:203-246, https://doi.org/10.1016/bs.abr.2018.10.003.

Birkás, Z., G. Balázs, and Z. Kókai. 2021. Effect of grafting and growing media on the chosen fruit quality compounds and sensory parameters of sweet pepper (Capsicum annuum L.). Acta Aliment. 50:1-12, https://doi.org/10.1556/ 066.2020 .00016

Bosland, P.W. 2016. Vegetable cultivar descriptions for North America - Pepper (M-Z). 28 Feb. 2021. <https://cucurbitbreeding.wordpress. ncsu.edu/2016/06/03/pepper-m-z/>.

Colla, G., Y. Rouphael, C. Leonardi, and Z. Bie. 2010. Role of grafting in vegetable crops grown under saline conditions. Scientia Hort. 127:147155, https://doi.org/10.1016/j.scienta.2010.08.004.

Collins, M.D., L.M. Wasmund, and P.W. Bosland. 1995. Improved method for quantifying capsaicinoids in Capsicum using high-performance liquid chromatography. HortScience 30:137-139, https://doi.org/10.21273/HORTSCI.30.1.137.

Davis, A.R., P. Perkins-Veazie, R. Hassell, A. Levi, S.R. King, and X. Zhang. 2008. Grafting effects on vegetable quality. HortScience 43:1670 1672, https://doi.org/10.21273/HORTSCI.43.6. 1670. 
Devi, P., S. Lukas, and C.A. Miles. 2020. Fruit maturity and quality of splice-grafted and onecotyledon grafted watermelon. HortScience 55: 1090-1098, https://doi.org/10.21273/HORTSCI 15045-20.

Devi, P., L. Tymon, A. Keinath, and C.A. Miles. 2021. Progress in grafting watermelon to manage Verticillium wilt. Plant Pathol. 70:767-777, https://doi.org/10.1111/ppa.13344.

Doñas-Uclés, F., D. Pérez-Madrid, C. Amate-Llobregat, E.M. Rodríguez-García, and F. Camacho-Ferre. 2015. Production of pepper cultivar Palermo grafted onto Serrano de Morelos 2, Jalapeño, and three commercial rootstocks. HortScience 50:1018-1022, https://doi.org/ 10.21273/HORTSCI.50.7.1018.

Duan, X., H. Bi, T. Li, G. Wu, Q. Li, and X. Ai. 2017. Root characteristics of grafted peppers and their resistance to Fusarium solani. Biol. Plant. 61:579-586, https://doi.org/10.1007/ s10535-016-0677-4.

Fisk, T. 2017. Quality changes in grafted pepper (Capsicum annumm L.) scion fruit. The Ohio State Univ., Columbus, MS Thesis.

Frey, C.J., X. Zhao, J.K. Brecht, D.M. Huff, and Z.E. Black. 2020. High tunnel and grafting effects on organic tomato plant disease severity and rootknot nematode infestation in a subtropical climate with sandy soils. HortScience 55:46-54, https://doi.org/10.21273/HORTSCI14166-19.

Grieneisen, M.L., B.J. Aegerter, C.S. Stoddard, and M. Zhang. 2018. Yield and fruit quality of grafted tomatoes, and their potential for soil fumigant use reduction. A meta-analysis. Agron. Sustain. Dev. 38:1-16, https://doi.org/10.1007/ s13593-018-0507-5.

Guan, W., X. Zhao, R. Hassell, and J. Thies. 2012. Defense mechanisms involved in disease resistance of grafted vegetables. HortScience 47: 164-170, https://doi.org/10.21273/HORTSCI. 47.2.164.

Gutiérrez-Benites, E.D. 2018. Effects of grafting tropical rootstocks on yield and fruit quality in tomato (Solanum lycopersicum L.). Univ. of Wisconsin-Madison, Madison, MS Thesis.

Haroldsen, V., M.W. Szczerba, H. Aktas, J. López, M.J. Odias, C.L. Chi-Ham, J. Labavitch, A.B. Bennett, and A.L. Powell. 2012. Mobility of transgenic nucleic acids and proteins within grafted rootstocks for agricultural improvement. Front. Plant. Sci. 3:39, https://doi.org/ 10.3389/fpls.2012.00039.

Jang, Y., E. Yang, M. Cho, Y. Um, K. Ko, and C. Chun. 2012. Effect of grafting on growth and incidence of Phytophthora blight and bacterial wilt of pepper (Capsicum annuum L.). Hort. Environ. Biotechnol. 53:9-19, https://doi.org/ 10.1007/s13580-012-0074-7.

Johnson, T.S., G. Ravishankar, and L. Venkataraman. 1996. Biotransformation of ferulic acid and vanillylamine to capsaicin and vanillin in immobilized cell cultures of Capsicum frutescens. Plant Cell Tissue Organ Cult. 44:117-121, https://doi.org/10.1007/BF00048188.

Karaca, M., A.G. Ince, and U.K. Reddy. 2020. Interspecific grafting between Gossypium hirsutum, G. barbadense and G. herbaceum lines. Scientific Rpt. 10:1-12, https://doi.org/10.1038/ s41598-020-75679-1.

Kim, J., M. Park, D.J. Lee, and B. Kim. 2009. Characterization of putative capsaicin synthase promoter activity. Mol. Cells 28:331-339, https://doi.org/10.1007/s10059-009-0128-6.

Kim, S., M. Park, S. Yeom, Y. Kim, J.M. Lee, H. Lee, E. Seo, J. Choi, K. Cheong, and K. Kim. 2014. Genome sequence of the hot pepper provides insights into the evolution of pungency in
Capsicum species. Nat. Genet. 46:270-278, https://doi.org/10.1038/ng.2877.

Knuteson, D.L., W.R. Stevenson, J.A. Wyman, A.J. Bussan, J.B. Colquhoun, C.A. Laboski, and E. Silva. 2010. A3844 BioIPM, Pepper Workbook. 19 Feb. 2020. < https://ipcm.wisc.edu/download/ pubsGuides/BioIPM_Pepper_web.pdf $>$.

Kumar, P., Y. Rouphael, M. Cardarelli, and G. Colla. 2017. Vegetable grafting as a tool to improve drought resistance and water use efficiency. Front. Plant. Sci. 8:1130, https://doi. org/10.3389/fpls.2017.01130.

Kyriacou, M.C., Y. Rouphael, G. Colla, R. Zrenner, and D. Schwarz. 2017. Vegetable grafting: The implications of a growing agronomic imperative for vegetable fruit quality and nutritive value. Front. Plant. Sci. 8:741, https://doi. org/10.3389/fpls.2017.00741.

Leal-Fernández, C., H. Godoy-Hernández, C.A. Núñez-Colín, J.L. Anaya-López, S. VillalobosReyes, and J.Z. Castellanos. 2013. Morphological response and fruit yield of sweet pepper (Capsicum annuum L.) grafted onto different commercial rootstocks. Biol. Agr. Hort. 29:1-11, https://doi.org/10.1080/01448765.2012.746063.

Lee, J., C. Kubota, S.J. Tsao, Z. Bie, P.H. Echevarria, L. Morra, and M. Oda. 2010. Current status of vegetable grafting: Diffusion, grafting techniques, automation. Scientia Hort. 127:93-105, https://doi.org/10.1016/j.scienta.2010.08.003.

Li, S., X. Wang, W. Xu, T. Liu, C. Cai, L. Chen, C.B. Clark, and J. Ma. 2021. Unidirectional movement of small RNAs from shoots to roots in interspecific heterografts. Nat. Plants 7:50-59, https://doi.org/10.1038/s41477-020-00829-2.

McAvoy, T., J.H. Freeman, S.L. Rideout, S.M. Olson, and M.L. Paret. 2012. Evaluation of grafting using hybrid rootstocks for management of bacterial wilt in field tomato production. HortScience 47:621-625, https://doi.org/ 10.21273/HORTSCI.47.5.621.

Mamphogoro, T.P., O.O. Babalola, and O.A. Aiyegoro. 2020. Sustainable management strategies for bacterial wilt of sweet peppers (Capsicum annuиm) and other Solanaceous crops. J. Appl. Microbiol. 129:496-508, https://doi.org/10.1111/ jam. 14653.

Martin, A., H. Adam, M. Diaz-Mendoza, M. Zurczak, N.D. González-Schain, and P. SuárezLópez. 2009. Graft-transmissible induction of potato tuberization by the microRNA miR172. Development 136:2873-2881, https://doi.org/ 10.1242/dev.031658

Mora-Bolaños, J. and J. Mora-Barrantes. 2014. Memoria del Consorcio Local de Innovación Tecnológica Agropecuaria en Chile Dulce. Instituto Nacional de innovación y Transferencia en tecnología Agropecuaria. 28 Feb. 2021. $<$ http://www.mag.go.cr/bibliotecavirtual/F3010875.pdf $\geq$.

Navarro, C., J.A. Abelenda, E. Cruz-Oró, C.A. Cuéllar, S. Tamaki, J. Silva, K. Shimamoto, and S. Prat. 2011. Control of flowering and storage organ formation in potato by FLOWERING LOCUS T. Nature 478:119-122, https://doi.org/ 10.1038/nature10431.

Ohta, Y. 1991. Graft-transformation, the mechanism for graft-induced genetic changes in higher plants. Euphytica 55:91-99, https://doi.org/ 10.1007/BF00022565.

Osborne Quality Seed. 2021. Gypsy F1 untreated pepper. 28 Feb. 2021. <https://www.osborneseed. com/catalog/item-content76603/gypsy-f1/pr_76603/ $\mathrm{cp} /$ catalog/vegetables/aas-winners/pepper $>$.

PanAmerican Seed Company. 2021. Aji Rico Pepper. $28 \mathrm{Feb} .2021 .<$ https://www.panamseed. com/plant_info.aspx?phid $=048300001036967>$.
Pant, B.D., A. Buhtz, J. Kehr, and W.R. Scheible. 2008. MicroRNA399 is a long-distance signal for the regulation of plant phosphate homeostasis. Plant J. 53:731-738, https://doi.org/10.1111/ j.1365-313X.2007.03363.x.

Padilla, Y.G., R. Gisbert-Mullor, L. López-Serrano, S. López-Galarza, and Á. Calatayud. 2021. Grafting enhances pepper water stress tolerance by improving photosynthesis and antioxidant defense systems. Antioxidants 10:576, https:// doi.org/10.3390/antiox10040576.

Penella, C., S.G. Nebauer, S. López-Galarza, A. Quiñones, A. San Bautista, and Á. Calatayud. 2017. Grafting pepper onto tolerant rootstocks: An environmental-friendly technique overcome water and salt stress. Scientia Hort. 226:33-41, https://doi.org/10.1016/j.scienta.2017.08.020.

Penella, C., S.G. Nebauer, A. San Bautista, S. LópezGalarza, and Á. Calatayud. 2015. Strategies to avoid salinity and hydric stress of pepper grafted plants. Procedia Environ. Sci. 29:211-212, https://doi.org/10.1016/j.proenv.2015.07.267.

Rivard, C.L., S. O'Connell, M.M. Peet, R.M. Welker, and F.J. Louws. 2012. Grafting tomato to manage bacterial wilt caused by Ralstonia solanacearum in the southeastern United States. Plant Dis. 96:973-978, https://doi.org/ 10.1094/PDIS-12-10-0877.

Ropokis, A., G. Ntatsi, C. Kittas, N. Katsoulas, and D. Savvas. 2019. Effects of temperature and grafting on yield, nutrient uptake, and water use efficiency of a hydroponic sweet pepper crop. Agronomy (Basel) 9:110, https:// doi.org/10.3390/agronomy9020110.

Sabatino, L., G. Iapichino, F. D’Anna, E. Palazzolo, G. Mennella, and G.L. Rotino. 2018 Hybrids and allied species as potential rootstocks for eggplant: Effect of grafting on vigour, yield and overall fruit quality traits. Sci. Hort. 228:81:90, doi: https://doi.org/10.1016/j. scienta.2017.10.020.

Sánchez-Chávez, E., A. Torres González, M.A. Flores Córdova, P. Preciado Rangel, and C. Márquez Quiroz. 2015. Uso de portainjerto sobre el rendimiento, calidad del fruto y resistencia a Phytophthora capsici Leonian en pimiento morrón. Nova Sci. 7:227-244.

Soltan, M., F. ElAidy, J. Scheerens, and M. Kleinhenz. 2017. Grafting, scion and rootstock effects on survival rate, vegetative growth and fruit yield of high tunnel-grown grafted pepper (Capsicum annuum L.) plants. Adv. Crop. Sci. Tech. 5:2, https://doi.org/10.4172/2329-8863.1000312.

Stewart, C., B. Kang, K. Liu, M. Mazourek, S.L. Moore, E.Y. Yoo, B. Kim, I. Paran, and M.M. Jahn. 2005. The Punl gene for pungency in pepper encodes a putative acyltransferase. Plant $\mathrm{J}$. 42:675-688, https://doi.org/10.1111/j.1365-313X. 2005.02410.x.

Stewart, C., M. Mazourek, G.M. Stellari, M. O'Connell, and M.M. Jahn. 2007. Genetic control of pungency in C. chinense via the PunI locus. J. Expt. Bot. 58:979-991, https://doi.org/ 10.1093/jxb/erl243.

Suchoff, D.H., F.J. Louws, and C.C. Gunter. 2019. Yield and disease resistance for three bacterial wilt-resistant tomato rootstocks. HortTechnology 29:330-337, https://doi.org/10.21273/HORT TECH04318-19.

Taller, J., N. Yagishita, and Y. Hirata. 1999. Graftinduced variants as a source of novel characteristics in the breeding of pepper (Capsicum annuum L.). Euphytica 108:73-78, https://doi.org/ 10.1023/A:1003681913996.

Taller, J., Y. Hirata, N. Yagishita, M. Kita, and S. Ogata. 1998. Graft-induced genetic changes and the inheritance of several characteristics in pepper (Capsicum annuum L.). Theor. Appl. Genet. 
97:705-713, https://doi.org/10.1007/s001220050 946.

Tsaballa, A., A. Xanthopoulou, P. Madesis, A. Tsaftaris, and I. Nianiou-Obeidat. 2021. Vegetable grafting from a molecular point of view; the involvement of epigenetics in rootstockscion interactions. Front. Plant. Sci. 11:621999, https://doi.org/10.3389/fpls.2020.621999.

Tsaballa, A., C. Athanasiadis, K. Pasentsis, I. Ganopoulos, I. Nianiou-Obeidat, and A. Tsaftaris. 2013. Molecular studies of inheritable grafting induced changes in pepper (Capsicum annuиm) fruit shape. Scientia Hort. 149:2-8, https://doi.org/10.1016/j.scienta.2012.06.018.

Vega-Alfaro, A.A. 2020. Fruit yield, maturity and survival rate of interspecific Capsicum graft combinations evaluated in tropical and temperate environments. Univ. of WisconsinMadison, Memorial Library, Madison, MS Thesis.
Vega-Alfaro, A.A., C. Ramirez, and J. Nienhuis. 2021. Promoting survival rate and reducing adventitious root formation in inter-species Capsicum grafting. Acta Hort. 1302:117-124, https:// doi.org/10.17660/ActaHortic.2021.1302.16.

Wada, K.C. and K. Takeno. 2010. Stress-induced flowering. Plant Signal. Behav. 5:944-947, https://doi.org/10.4161/psb.5.8.11826.

Warschefsky, E.J., L.L. Klein, M.H. Frank, D.H. Chitwood, J.P. Londo, E.J. von Wettberg, and A.J. Miller. 2016. Rootstocks: Diversity, domestication, and impacts on shoot phenotypes. Trends Plant Sci. 21:418-437, https://doi.org/ 10.1016/j.tplants.2015.11.008.

Wu, R., X. Wang, Y. Lin, Y. Ma, G. Liu, X. Yu, S. Zhong, and B. Liu. 2013. Inter-species grafting caused extensive and heritable alterations of DNA methylation in Solanaceae plants. PLoS One 8:e61995, https://doi.org/10.1371/ journal.pone.0061995.
Yagishita, N. and Y. Hirata. 1986. Genetic nature of bushy plant type in the variant strain induced by grafting in Capsicum annuum $\mathrm{L}$. Euphytica 35:17-23, https://doi.org/10.1007/ BF00028536.

Yagishita, N. and Y. Hirata. 1987. Graftinduced change in fruit shape in Capsicum annuит L genetic analysis by crossing. Euphytica 36:809-814, https://doi.org/10.1007/ BF00051864.

Yagishita, N., Y. Hirata, H. Mizukami, H. Ohashi, and K. Yamashita. 1990. Genetic nature of low capsaicin content in the variant strains induced by grafting in Capsicum annuum L. Euphytica 46:249-252, https://doi.org/10.1007/BF00027224.

Yagishita, N., Y. Hirata, K. Okochi, K. Mimura, H. Mizukami, and H. Ohashi. 1985. Characterization of graft-induced change in capsaicin content of Capsicum annuum L. Euphytica 34:297-301, https://doi.org/10.1007/BF00022922. 